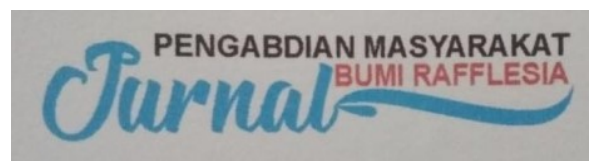

\title{
Tata Kelola Adminitrasi Desa Tepi Laut Kecamatan Air Napal Kabupaten Bengkulu Utara
}

\author{
Onsardi $^{1}$, Ahmad Sumarlan ${ }^{2}$, Meilaty Finthariasari ${ }^{3}$ \\ ${ }^{1,3}$ Program Studi Manajemen \\ ${ }^{2}$ Program Studi Akuntansi \\ Fakultas Ekonomi Universitas Muhammadiyah Bengkulu \\ Correponding author : onsardi@umb.ac.id
}

\begin{abstract}
ABSTRAK
Permasalahan yang dihadapi oleh perangkat desa, Desa Tepi Laut Kecamatan Air Napal Kabupaten Bengkulu Utara dalam pengelolaan administrasi desa adalah bahwa sumber daya manusia masih berpendidikan relatif rendah, penguasan tehnologi yang masih kurang khususnya penguasaan penggunaan komputer, perangkat desa masih kurang mendapat pelatihan. Tujuan yang ingin dicapai adalah memberikan pengetahuan yang memadai mengenai administrasi desa, memberikan pelatihan berbasis komputer tentang administrasi desa. Metode pelaksanaan kegiatan yang digunakan adalah dalam bentuk pelatihan kepada seluruh perangkat desa yang berhubungan langsung dengan pengelolaan administrasi desa. Metode pelatihan tersebut di atas diimplementasikan dalam tiga tahapan yaitu (1) sosialisasi, (2) peningkatan kompetensi dan peningkatan skill, (3) monitoring dan evaluasi. Hasil pelatihan ini adalah (1) peningakatan penguasaan dan kemampuan perangkat desa dalam pengelolaan administrasi desa, (2) peningkatan ketrampilan perangkat desa dalam penggunaan teknologi komputer dalam pengelolaan administrasi desa.
\end{abstract}

\section{Keywords : Pelatihan, Administrasi Desa.}

\section{PENDAHULUAN}

Desa Tepi Laut adalah sebuah wilayah dalam cakupan, Kecamatan Air Napal, Kabupaten Bengkulu Utara, Propinsi Bengkulu. Sebelah barat berbatasan dengan Samudra Indonesia, sebelah utara berbatasan dengan Desa Pasar Kerkap, sebelah timur berbatasan dengan Desa Turanmumpo dan Desa Senaba, sebelah selatan berbatasan dengan Desa pasar Bembah. Luas Wilayah Desa Tepi Laut adalah \pm 700 hektar dan jumlah kepala keluarga sebanyak 199 KK, penghasilan pokok penduduk desa ini adalah dari sektor perkebunan dan pertanian (Kantor Desa, 2018).

Untuk melaksanakan aktivitas pemerintahan desa, Desa Tepi Laut di pimpin oleh seorang kepala desa yang dibantu oleh sekretaris desa, bendahara desa, kepala urusan, kasi kepala dusun dan empat orang staf administrasi. Permasalahan pokok yang dihadapi oleh perangkat desa, Desa Tepi Laut Kecamatan Air Napal Kabupaten Bengkulu Utara dalam pengelolaan administrasi desa adalah sumber daya manusia masih berpendidikan relatif rendah, penguasan tehnologi yang masih kurang khususnya penguasaan penggunaan komputer, perangkat desa masih kurang mendapat pelatihan. Tentu hal ini berdampak kepada pelayanan yang diberikan kepada masyarakat khususnya bidang adminsitrasi dan pengelolaan keuangan desa. Untuk itu perlu pengelolaan administrasi dan keuangan desa tersebut secara baik dan benar, tentu 
saja hal ini diperlukan tata kelola pamong desa dan tata kelola administrasi desa yang sesuai dengan peraturan yang berlaku. Sistem adminsitrasi yang standar diperlukan dalam pengelolaan desa tesebut. Pelatihan adalah salah satu cara agar pengelolaan administrasi dapat dilaksanakan dengan baik dan benar oleh perangkat desa.

\section{Pelatihan}

Menurut Zainal, et al. (2014), pelatihan adalah proses secara sistematis mengubah tingkah laku pegawai untuk mencapai tujuan organisasi. Pelatihan berkatian dengan keahlian dan kemampuan pegawai untuk melaksanakan pekerjaan saat ini. Pelatihan memiliki orientasi saat ini dan membantu pegawai untuk mencapai kehalian dan kemampuan tertentu agar berhasil dalam melaksanakan pekerjaanya.

Lubis (2008) definisi pelatihan adalah: proses belajar mengajar dengan menggunakan teknik dan metode tertentu secara konsepsional dapat dikatakan bahwa latihan dimaksudkan untuk meningkatkan keterampilan dan kemampuan kerja seseorang atau sekelompok orang. Biasanya yang sudah bekerja pada suatu organisasi yang efisiensi, efektivitas dan produktivitas kerjanya dirasakan perlu untuk dapat ditingkatkan secara terarah dan pragmatik.

Menurut Bernadin dan Russel (2010), pelatihan adalah setiap usaha untuk memperbaiki performasi tanggungjawabnya, atau satu pekerjaan yang ada kaitannya dengan pekerjaannya.

Dari beberapa pengertian di atas, dapat dikatakan bahwa pelatihan merupakan salah satu upaya perusahaan untuk meningkatkan kinerja agar mereka dapat bekerja dengan baik dan dapat memberikan kualitas pelayanan yang baik pula kepada masyarakat.

\section{Tujuan Pelatihan}

Menurut Carrel (2011) mengemukakan delapan tujuan utama program pelatihan antara lain:

a. Memperbaiki kinerja. b. Meningkatkan keterampilan karyawan.

c. Menghindari Keusangan manajerial.

d. Memecahkan permasalahan.

e. Orientasi karyawan baru.

f. Persiapan promosi dan keberhasilan manajerial

g. Memperbaiki kepuasan untuk kebutuha

h. Pengembangan personel karyawannya, maka perlu terlebih dahulu dijelaskan apa yang menjadi sasaran daripada pelatihan tersebut.

Dalam pelatihan tersebut ada beberapa sasaran utama yang ingin dicapai menurut Umar (2013) mengemukakan bahwa "Program pelatihan bertujuan untuk emperbaiki penguasaan berbagai keterampilan dan teknik pelaksanaan kerja untuk kebutuhan sekarang". Pelatihan juga bertujuan agar peserta pelatihan cepat berkembang, sebab sulit bagi seseorang untuk mengembangkan diri hanya berdasarkan pengalaman tanpa adanya suatu pendidikan khusus. Ini membuktikan bahwa pengembangan diri akan lebih cepat melalui palatihan.

\section{Prinsip-prinsip Pelatihan}

Menurut Zainal, et al. (2014) mengemukakan lima prinsip pelatihan sebagai berikut:

1. Participation, artinya dalam pelaksanaan pelatihan para peserta harus ikut aktif karena dengan partisipasi peserta akan lebih cepat menguasai dan mengetahui berbagai materi yang diberikan.

2. Repetition, artinya senantiasa dilakukan secara berulang karena dengan ulangan-ulangan ini peserta akan lebih cepat untuk memenuhi dan mengingat apa yang telah diberikan.

3. Relevance, artinya harus saling berhubungan sebagai contoh para peserta pelatihan terlebih dahulu diberikan penjelasan secara umum tentang suatu pekerjaan sebelum mereka mempelajari hal-hal khusus dari pekerjaan tersebut.

4. Transference, artinya program pelatihan harus disesuaikan dengan kebutuhan-kebutuhan yang nantinya 
akan dihadapi dalam pekerjaan yang sebenarnya.

5. Feedback, artinya setiap program pelatihan yang dilaksanakan selalu dibutuhkan umpan balik yaitu untuk mengukur sejauh mana keberhasilan dari program pelatihan tersebut.

\section{Kebutuhan Pelatihan}

Menurut Zainal, et al. (2005), pelatihan akan berhasil jika proses mengisi kebutuhan pelatihan yang benar. Pada dasarnya kebutuhan itu adalah untuk memenuhi kekurangan pengetahuan, meningkatkan keterampilan, atau sikap dengan masing-masing pegawai yang bervariasi, (Onsardi, 2018). Kebutuhan pelatihan dapat digolongkan menjadi:

1. Kebutuhan memenuhi tuntutan sekarang. Kebutuhan ini biasanya dapat dikenali dari prestasi karyawannya yang tidak sesuai dengan standar hasil kerja yang dituntut pada jabatan itu.

2. Memenuhi kebutuhan tuntutan jabatan lainnya. Pada tingkat hierarki manapun dalam perusahaan sering dilakukan rotasi jabatan. Alasannya bermacammacam, ada yang menyebutkan untuk mengatasi kejenuhan, ada juga yang menyebutkan untuk membentuk orang generalis.

3. Untuk memenuhi tuntutan perubahan. Perubahan-perubahan baik intern (perubahan sistem, struktur organisasi) maupun ekstern (perubahan teknologi, perubahan orientasi bisnis perusahaan) sering memerlukan adanya tambahan pengetahuan baru.

Meskipun pada saat ini tidak ada persoalan antara kemampuan orangnya dengan tuntutan jabatannya, tetapi dalam rangka menghadapi perubahan di atas dapat diantisipasi dengan adanya pelatihan yang bersifat potensial.

\section{Administrasi Desa}

Secara terminologi, yang disebut administrasi adalah mengurus, mengatur, mengelola (Ali F, 2011). Lebih lanjut lagi Anggara S, (2012) administrasi adalah segenap rangkaian penataan terhadap pekerjaan pokok yang dilakukan oleh sekelompok orang dalam kerja sama mencapai tujuan tertentu. Dari dua pendapat ini jelas bahwa administrasi itu adalah kegiatan mengurus, mengatur menata dan mengelola terhadap suatu pekerjaan untuk mencapai tujuan.

Dari pendapat di atas juga dapat dimaknai bahwa administrasi desa sebagai kegiatan pengelolaan admnistrasi yang dilakukan di suatu wilayah pedesaan, karena administrasi desa merupakan keseluruhan proses kegiatan pencatatan data dan informasi mengenai penyelenggaraan pemerintahan Desa pada buku Administrasi Desa.

Setiap desa harus memiliki buku register desa, berdasarkan Peraturan Menteri Dalam Negeri Nomor 32 Tahun 2006 Tentang Pedoman Administrasi Desa, pada tahun 2016 sudah diubah dengan Peraturan Menteri Dalam Negeri Republik Indonesia Nomor 47 Tahun 2016 Tahun Tentang Administrasi Pemerintahan Desa, yang di dalamnya memuat tentang (1) Administrasi Umum; (2) Administrasi Penduduk; (3) Administrasi Keuangan; (4) Administrasi Pembangunan; dan (5) Administrasi Lainnya.

Pada kajian artikel ini akan dibahas terbatas pada pengelolaan admnstrasi desa yaitu (1) Administrasi Umum; (2) Administrasi Penduduk, selebihnya akan dibahas pada artikel berikutnya.

\section{METODE KEGIATAN}

Pelaksanaan kegiatan pengabdian dilakukan pada Desa Tepi Laut Kecamatan Air Napal Bengkulu utara dari tanggal 24 Juli s.d 10 September 2018. Metode pelaksanaan kegiatan yang digunakan adalah dalam bentuk pelatihan kepada seluruh perangkat desa yang berhubungan langsung dengan pengelolaan administrasi desa, pelatihan dilakukan berbasis komputer penggunaan MS Word dan Excel. Selanjutnya dengan metode pelatihan tersebut di atas akan diimplementasikan dalam tiga tahapan yaitu (1) sosialisasi, (2) peningkatan kompetensi dan peningkatan skill, (3) monitoring dan evaluasi. Peserta dalam 
pelatihan berjumlah 15 orang terdiri dari Kepala Desa, Sekdes, Bendahara, Kaur 5 orang, 4 orang staff desa dan 3 orang kepala dusun.

\section{HASIL DAN PEMBAHASAN}

Pengelolaan administrasi desa merupakan suatu kewajiban yang harus dilakukan. Dengan tertibnya administrasi desa yang baik, maka akan terbentuk tata pemerintahan yang baik pula, pembangunan berjalan lancar dan pelayanan kepada masyarakat akan semakin baik. Agar tercipta penyelenggaraan pemerintahan desa yang baik, maka pemerintah desa harus didukung oleh administrasi desa yang benar serta pemberdayaan kepada karyawan yang baik pula (Onsardi, A., Asmawi, M., \& Abdullah, T. (2017). Administrasi desa adalah keseluruhan proses kegiatan pencatatan data dan informasi mengenai penyelenggaraan pemerintahan desa pada buku administrasi desa.

Mengelola administrasi desa pada saat ini sangatlah penting. Ada milyaran rupiah yang dikucurkan dari pemerintah melalui APBN dan APBD kepada desa. Jika administrasi desa yang dilaksanakan hanya asal-asalan, hal itu akan mengakibatkan kurang tertibnya administrasi di desa-desa. Sistem administrasi desa yang baik dan benar akan menciptakan tertib administrasi, yaitu dapat menyajikan data dan informasi yang mudah bagi masyarakat dan bagi pemerintah desa dalam membuat kebijakan (Mouw E dan Keradjaan H, 2016).

Pelatihan administrasi desa di Desa Tepi Laut Kecamatan Air Napal Bengkulu Utara dilaksanakan dengan metode ceramah, diskusi dan praktik kerja yang dilaksanakan secara pendampingan dengan menggunakan media komputer. Aplikasi komputer yang digunakan adalah MS Word dan Excel. Peserta dalam pelatihan adalah semua perangkat desa yang berjumlah 15 orang. Pelatihan dilaksanakan tujuhbelas kali pertemuan dengan durasi waktu tiga jam satu kali pertemuan, total waktu pertemuan materi dan praktek adalah 51 jam.

Pada awal pertemuan pelatihan dilaksanakan terlebih dahulu sosialisasi tentang adminitrasi pemerintahan desa sesuai Peraturan Menteri Dalam Negeri Republik Indonesia Nomor 47 Tahun 2016. Saat sosialisasi ini menjelaskan betapa pentingnya adminitrasi desa itu dalam rangka tertibnya semua dokumendokumen desa untuk meningkatkan pelayanan kepada masyarakat.

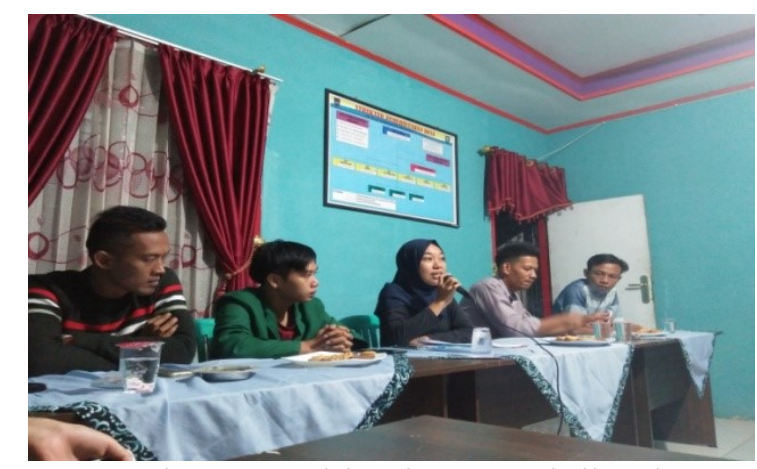

Dokumentasi kegiatan sosialisasi

Selanjutnya adalah peningkatan kompetensi perangkat desa dengan cara melatih mereka menggunakan komputer dengan aplikasi Offices MS Word dan Excel dalam penggelolaan administrasi desa. Dengan komputer dapat menyimpan data dan tertatanya dengan baik arsip desa yang dapat dipanggil atau digunakan kapan dibutuhkan.

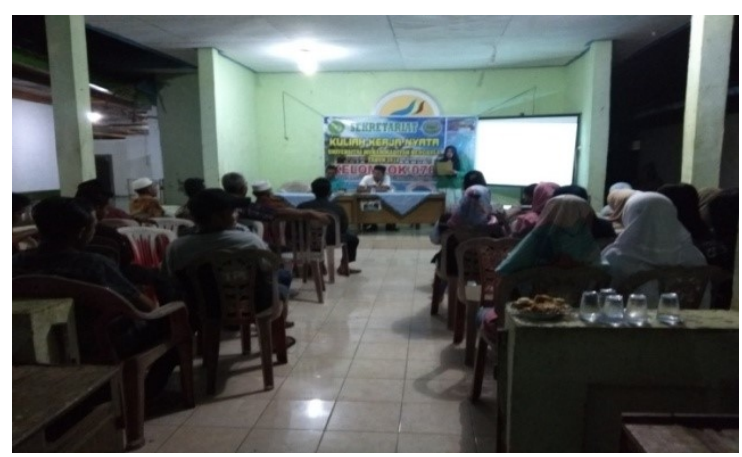

Dokumentasi pelaksanaan pelatihan adalah:

Adapun materi pelatihan tersebut

1. Administrasi Umum

Adminitrasi umum adalah pencatatan data dan informasi mengenai kegiatan pemerintahan Desa pada Buku 
Administrasi Umum. Buku ini register sebagai berikut:

a. Buku Peraturan Di Desa;

b. Buku Keputusan Kepala Desa;

c. Buku Inventaris dan Kekayaan Desa;

d. Buku Aparat Pemerintah Desa;

e. Buku Tanah Kas Desa;

f. Buku Tanah di Desa;

g. Buku Agenda;

h. Buku Ekspedisi; dan

i. Buku Lembaran Desa dan Buku Berita Desa.

2. Administrasi Penduduk

Administrasi penduduk adalah kegiatan pencatatan data dan informasi mengenai kependudukan pada Buku Administrasi Penduduk. Buku ini terdiri dari register sebagai berikut:

a. Buku Induk Penduduk;

b. Buku Mutasi Penduduk Desa;

c. Buku Rekapitulasi Jumlah

Penduduk;

d. Buku Penduduk Sementara; dan

e. Buku Kartu Tanda Penduduk dan

Buku Kartu Keluarga

Capaian hasil pelatihan administrasi desa pada Desa Tepi Laut Kecamatan Air Napal Kabupaten Bengkulu Utara dapat dilihat pada tabel berikut:

Tabel 1.

Capaian Pelatihan Tata Kelola Administrasi Desa

\begin{tabular}{lllll}
\hline Nama Kegiatan & Sebelum & Sesudah & Capaian & Ket. \\
\hline Administrasi Umum: & & & & \\
1. $\quad$ Buku Peraturan Di Desa; & belum ada & ada & $100 \%$ & file \\
2. Buku Keputusan Kepala Desa; & belum ada & ada & $100 \%$ & file \\
3. Buku Inventaris dan Kekayaan Desa; & belum ada & ada & $100 \%$ & file \\
4. Buku Aparat Pemerintah Desa; & belum ada & ada & $100 \%$ & file \\
5. Buku Tanah Kas Desa; & belum ada & ada & $100 \%$ & file \\
6. Buku Tanah di Desa; & belum ada & ada & $100 \%$ & file \\
7. Buku Agenda; & ada & ada & $100 \%$ & file \\
8. Buku Ekspedisi; dan & belum ada & ada & $100 \%$ & file \\
9. Buku Lembaran Desa dan Buku Berita & belum ada & ada & $100 \%$ & file \\
$\quad$ Desa. & & & & \\
Adminitrasi Penduduk: & & & $100 \%$ & file \\
1. Buku Induk Penduduk; & & ada & $100 \%$ & file \\
2. Buku Mutasi Penduduk Desa; & belum ada & ada & file \\
3. Buku Rekapitulasi Jumlah Penduduk; & belum ada & ada & $100 \%$ & file \\
4. Buku Penduduk Sementara; dan & belum ada & ada & $100 \%$ & file \\
5. Buku Kartu Tanda Penduduk dan & belum ada & ada & $100 \%$ & \\
\multicolumn{2}{l}{ Buku Kartu Keluarga } & & &
\end{tabular}

Dari tabel di atas kelihatan dengan jelas bahwa buku-buku administrasi desa yang masih banyak sekali yang belum dilaksanakan. Setelah dilaksanakan pelatihan semua buku-buku tersebut dibuat dengan bagus dan baik oleh perangkat desa dan tersimpan dengan file-file yang ada pada komputer desa.

Tahapan terakhir adalah monitoring dan evaluasi. Monitoring dan evaluasi dilaksanakan pada setiap sesi setelah berakhir materi per buku adaministrasi desa. Tujuannya adalah untuk mengetahui sejauhmana penguasaan materi yang telah diberikan kepada peserta pelatihan. Hasil evaluasi menunjukkan bahwa peningkatan penguasaan dan pemahaman serta keterampilan peserta pelatihan dalam penggelolaan administrasi desa pada Desa Tepi Laut Air Napal Bengkulu Utara.

\section{PENUTUP}

Dari pembahasan di atas hasil pengabdian ini dapat disimpulkan sebagai berikut:

a. Sosialisasi dilaksanakan sesuai dengan Peraturan Menteri Dalam Negeri Republik Indonesia Nomor 47 Tahun 2016 tentang administrasi pemerintahan desa. Saat sosialisasi 
dijelaskan pentingnya administrasi desa dalam rangka tertibnya semua dokumen-dokumen desa untuk meningkatkan pelayanan kepada masyarakat.

b. Peningkatan kompetensi perangkat desa dengan cara melatih mereka menggunakan komputer dengan aplikasi Offices MS Word dan Excel dalam penggelolaan administrasi desa. c. Monitoring dan evaluasi dilaksanakan pada waktu berakhirnya setiap sesi materi pelatihan. Tujuannya untuk mengetahui penguasaan materi yang telah diberikan kepada peserta pelatihan. Hasil evaluasi menunjukkan bahwa peningkatan penguasaan dan pemahaman serta keterampilan peserta pelatihan dalam penggelolaan administrasi desa.

\section{DAFTAR PUSTAKA}

Ali, Faried. 2011. Teori dan Konsep Administrasi: Dari Pemikiran Paradigmatik Menuju Redefinisi. Jakarta: Rajawali Press.

Anggara, Sahya. 2012. Ilmu Administrasi Negara (Kajian Konsep, Teori dan Fakta Dalam UpayaMenciptakan Good Governance). Bandung: CV. Pustaka Setia.

Bernardin, H.John and Russel. 2010. Human Resource Management. New York: McGrawHill

Husein Umar. 2013. Metode Penelitian untuk Skripsi dan Tesis. Jakarta: Rajawali.

Lubis, K.A. (2008). Pengaruh Pelatihan Dan Motivasi Kerja Terhadap Kinerja Karyawan Pada PT.Perkebunan Nusantara IV (PERSERO) Medan. Tesis, Universitas Sumatra Utara.

Michael R. Carrell (2011) Personnel: Human Resource Management. 4th Edition Northern Kentucky University

Mouw E dan Keradjaan H,. 2016. Pengelolaan Administrasi Pemerintahan Desa. Jurnal UNIERA Volume 5, Nomor 2.

Onsardi, A., Asmawi, M., \& Abdullah, T. (2017). The Effect Of Compensation, Empowerment, And Job Satisfaction On Employee Loyalty. International Journal of Scientific Research and Management, 5(12), 7590-7599.

Onsardi, O. (2018). Loyalitas Karyawan pada Universitas Swasta di Kota Bengkulu. Journal of Economic, Bussines and Accounting (COSTING), 2(1), 1-13.

Peraturan Menteri Dalam Negeri Republik Indonesia Nomor 47 Tahun 2016 Tentang Administrasi Pemerintahan Desa.

Universitas Muhammadiyah Bengkulu, 2018. Pedoman Prposal Pengabdian Masyarakat. LPPM

Zainal, Veithzal, Rivai, Mansyur Ramly, Thoby Mutis, Willy Arafah. Manajemen Sumber Daya Manusia untuk Perusahan Dari Teori ke Praktik-Edisi Ketiga. Jakarta: PT. RajaGrafindo, 2014. 